\title{
Obituary
}

\section{In Memoriam: Professor Dr. Frank M. Go, connecting the dots}

Place Branding and Public Diplomacy (2017) 13, 177-178. doi:10.1057/s41254-017-0061-y; published online 18 June 2017

On May 7th, sadly, Frank Go, distinguished professor and member of the editorial board of this journal passed away peacefully in his own home in Rotterdam. He had fought Leukaemia for a year and a half. It is yet another great loss for our place branding and tourism studies community. Frank's contribution to knowledge in terms of papers and books published, students supervised and fellow researchers assisted, is immeasurable. $\mathrm{He}$ was on the editorial board for over twenty journals, as well as our own. I had the great pleasure of working and collaborating with Frank for many years, and therefore I consider it a privilege to be able to share this in memoriam with you, which is personal, rather than focussing on Frank's accomplishments, which are many, amongst which co-authoring and co-editing at least five books on place branding.

Many colleagues will know that I enjoy recounting the story of my first ever meeting with Frank, in the summer of '96. Frank suggested meeting at the McDonald's restaurant in Amsterdam's Bijlmermeer. McDonald's not being the classiest of establishments and "De Bijlmer", at the time, being infamous as an Amsterdam "ban lieu/ghetto", this was not the obvious place one would expect to meet with a highly accomplished tourism and hospitality management professor. To me it became a metaphor for who Frank was. He was truly cosmopolitan, without prejudice, open and genuinely interested in people from all walks of life and cultures. He was impartial to status, protocol or appearances and in love with places; from the luxury resorts where he was invited as a speaker, to the bazaars of Istanbul. Frank himself had Indonesian, Chinese and Dutch ancestors, but was born (22 August 1948) and raised in Amsterdam and that clearly made him a non-conformist with an open mind.

During his last few weeks, Frank expressed repeatedly how grateful he was for the life and career that he had. He himself would not have referred to these as two different things, because his 'career' was not 'work' and the life that he was so grateful for was tremendously enriched as a result of the academic activities that he was 'allowed to' engage in. Not in the least because he loved to travel, meet people and get to know and understand their culture. Whenever he received personal invitations to visit colleagues abroad and stay at their home or share a meal with them privately, he would not hesitate, particularly if that meant that he could bring his beloved wife Quita along. Those were the memories he treasured and shared with others. Recounting conference trips, he would not recall his presentations or achievements, but he would share fond memories of meals and activities shared with others, ice cream on Barcelona's Ramblas, vol-au-vent in the student cafeteria in Leuven; a street kebab in Cairo, or the fancy conference organisers' dinner in Pori, Finland. He enjoyed it all, 
because of his genuine connection with people and their cultures; humble and indifferent to luxury, esteem or status.

Frank was the most visionary man I ever had the pleasure of working with. He was visionary in the literal sense that he was inimitable in his ability to look over the fence. He would connect ideas from all academic disciplines, cultures or timeframes. He was visionary in the figurative sense as he was sometimes hard to follow, considering his abstract helicopter view. As a $\mathrm{PhD}$ student, it often took me two weeks to figure out what he was working on, and on doing so, I was always amazed at his genius; always ahead of his time and seeing the linkages before anyone else did. Unfortunately, in today's bleep culture, this was not always to his advantage. Sometimes being stubborn and impatient, it could lead to frustration if students or peers could not match his abstract and unique analytical way of thinking, based on the constant devouring of literature and in attempts to link people and ideas across all disciplines. Yet, to anyone trying their best he would be empathic, supportive and inspiring; a true coach and mentor.

He certainly was not able to finish his work. The last time I met him, 13 days before him passing, we discussed his condition and life for about $45 \mathrm{~min}$, but surely, subsequently, we discussed the contemporary challenges of the world that we live in. In fact, the weeks before he had been calling friends and colleagues, asking them to visit in order to make new connections between people in a last attempt to tackle global challenges. In other words, his work would never have been finished, no matter how many dots he would try to connect and bridges he would try to build. He was an idealist, an ambitious man of ideas, an inspiring visionary innovator, to the extent that I often wondered how he was able to maintain that spirit in the world that we live in. Yet, on his deathbed, he was nothing short of being optimistic and courageous, grateful for his life that was touched by so many people and places, grateful for being able to say goodbye to those closest to him and grateful for his life with Quita and his two sons. It made me realise that even in the way he carried his fate he was a coach and mentor.

If what they say about dying is true, we hope to meet Frank again in bright light at golden arches. If not, may he rest in peace as his name will be deleted from so many lists of editorial boards, while his legacy lives on.

Robert Govers

With special thanks to fellow Go-protégé Erik van 't Klooster for his input.

Robert Govers

Antwerp, Belgium

E-mail: rgovers@rgovers.com 